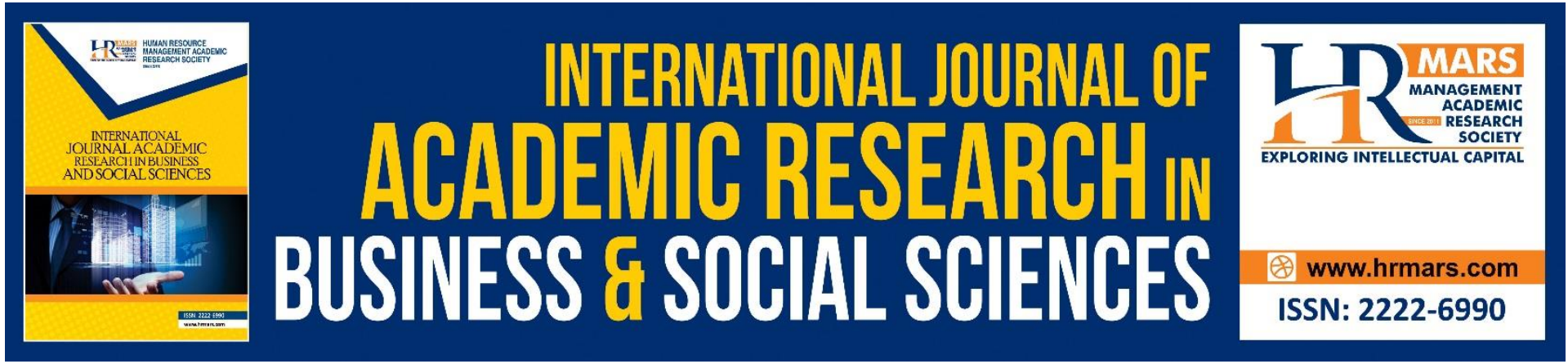

\title{
Corruption and Islamization in Malaysia
}

\section{Arena Che Kasim \& Suzana Mohd Hoesni}

To Link this Article: http://dx.doi.org/10.6007/IJARBSS/v11-i6/10256

DOI:10.6007/IJARBSS/v11-i6/10256

Received: 20 April 2021, Revised: 23 May 2021, Accepted: 04 June 2021

Published Online: 23 June 2021

In-Text Citation: (Kasim \& Hoesni, 2021)

To Cite this Article: Kasim, A. C., \& Hoesni, S. M. (2021). Corruption and Islamization in Malaysia. International Journal Academic Research in Business and Social Sciences, 11(6), 1206-1220.

Copyright: (c) 2021 The Author(s)

Published by Human Resource Management Academic Research Society (www.hrmars.com)

This article is published under the Creative Commons Attribution (CC BY 4.0) license. Anyone may reproduce, distribute, translate and create derivative works of this article (for both commercial and non-commercial purposes), subject to full attribution to the original publication and authors. The full terms of this license may be seen at: http://creativecommons.org/licences/by/4.0/legalcode

Vol. 11, No. 6, 2021, Pg. 1206 - 1220

http://hrmars.com/index.php/pages/detail/IJARBSS

JOURNAL HOMEPAGE

Full Terms \& Conditions of access and use can be found at http://hrmars.com/index.php/pages/detail/publication-ethics 


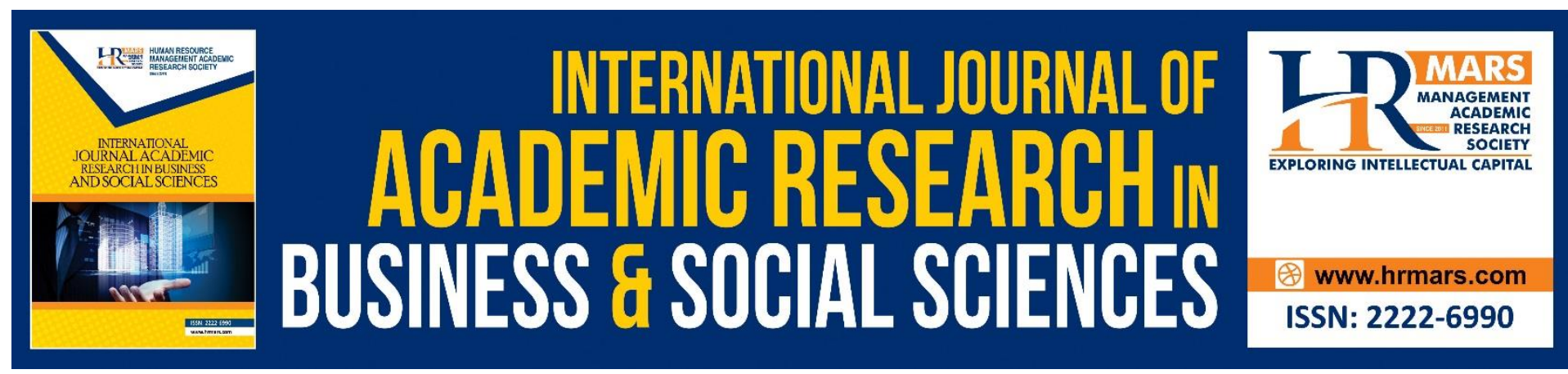

\title{
Corruption and Islamization in Malaysia
}

\author{
Arena Che Kasim \& Suzana Mohd Hoesni \\ Center for Research in Psychology and Human Well-Being, Faculty of Social Science and \\ Humanities, The National University of Malaysia, 43600 Bangi, Selangor, Malaysia \\ Email: arena@ukm.edu.my
}

\begin{abstract}
The current ethical and social dilemma experienced by each country globally has become more challenging. The increase in the case of fraud, malpractice and corruption among civil servants mainly is worrying globally as well as locally. Malaysia as a developing country is also no exception from this problem. Social moral problems recently grow rapidly and become more chronic regardless the age, race or religion. The writing of qualitative concept paper with analysis content method attempts to obtain an answer to the question of integrity, value among the community by introducing numerous of policy and inculcation of Islamic Value campaign since a decade ago. Therefore, this paper aims to analyse plans introduced by the government to overcome it and to what extends it give impacts on the integrity and value among the community and civil servants. The findings indicate all the campaigns, policies introduced have not affected the civil servants especially in their involvement in performing corruption acts and malpractice. It is hoped that a comprehensive and accurate plan can be introduced and implemented to all in the effort to form Malaysia as a country of zero corruption and malpractice.
\end{abstract}

Keywords: Islamization, Corruption, Malpractice, Fraud, Trustworthy

\section{Introduction}

The continuous efforts of Malaysia's government have successfully integrated the process of Islamization in various existing sectors in the country. Inculcation of Islamic Value Policy in the administration, for example, is one of the government efforts to apply Islamic Value in the administration. However, corruption and abuse of power are still one of the biggest problems experienced by the country. Corruption is the greatest challenge in the $21^{\text {st }}$ century that has affected all aspects of community life. Corruption and power abuse occurred everywhere in the government sector as well as in private departments in this country. The low integrity of community members especially civil servants has taken on a debate in news. A work culture of integrity refers to competitive work culture, having a clear mission and direction and has good morals and attitude (Akrimi \& Anuar, 2017). The effect of the lack of integrity in individuals and community causes corruption and malpractice to continue to grow and become one of the social diseases that coloured the civilization of the society for so long. This issue is universal without the limitation of time. There is no country in the world and system of government regardless of capitalist, socialist or communist who able to claim they are free 
from corruption (Fauzi, 2001). These phenomena have taken place in existing country blocks in the East and in the West.

\section{Literature Review}

Corruption is not only a human right issue but also a violation of human rights that can contribute to closing the gap of the implementation of international anti-corruption instruments and can complement the dominant criminal-based approach (Peters, 2019). Informal social control is an effective method of strengthening the value of integrity to restrict the misconduct of young people. Strong religious beliefs (Obasola, 2013) and followed by trust towards the Law Enforcement Agency (Costallo \& Vowell, 1999) is expected to increase the integrity value of youth, where the level of neglect for the non-integrity activity is high.

The practice of religion and volunteerism among the youth are expected to enhance moral value and integrity (Sufiean, et al., 2018). The religious aspect has a significant relationship with social integration among the people under surveillance (Fauziah et al., 2020). This shows that religion is crucial that works as a human driver to practice a good and respected attitude. A work culture of integrity refers to competitive work culture, having a clear mission and direction and has good morals and attitude (Akrimi \& Anuar, 2017).

To own honest, responsible, trustworthy, sincere and transparent attitude in performing work is important for the individual. This is because these values can help to build and form human integrity (Hafizah, 2019). The level of piety towards the religion, religious practice, and the trust towards the agency of law enforcement able to increase the moral value and integrity of the young people (Sufiean, et al., 2018). The understanding and practice of continuous integrity attitude is a strong base to curb the problem of corruption and misconduct problems continue to be uncontrolled.

\section{Methodology}

The research is in a qualitative form that using the content analysis method. This method is used because further discussions are using data and information from government official documents as well as analysis of findings from the past study. This is to ensure the authenticity and accuracy of the information discussed in finding answers to questions regarding corruption and Islamization in Malaysia.

\section{Corruption in Malaysia}

The word rasuah is derived from Arabic 'ar-Risywah' that means as a connector who can deliver the purpose with the bribe of goods and property (Yang, 2007). According to World Bank (2008), corruption is one of the biggest obstacles in the development of the economy and social. Balckburn (2009) stated that corruption is the abuse of power by civil servants to maximise personal gain. Corruption is a selfish act and ignoring and unfair to the community they live in. Corruption and abuse of power are the contagious diseases that is not less influence and appropriately to fight against it as we combat the problem of drug and other social diseases.

Drug abuse, corruption and power abuse can influence people live individually, families, communities, nations and country. The attitude of giving and receiving bribes and abusing the existing and given power able also can spread from parents to children, leaders or employers 
to employees, senior to junior and vice versa. As long as there is the hand of giving, there will be the hand of receiving and recipient. Even though in kindness and charity, the hand that gives is better than the receiving hand, but in this context, there is no benefit for both the behaviour, in fact is forbidden and despicable by the religion and community. Meaning "Do not eat up one another's property among yourself by false means (unjustly)" (QS. Al Baqarah:188). Prophet Muhammad S.A.W in the hadith also cursed both sides who give or receive bribes.

The data provided is related to arrests of corruption from 2015-2019 by taken from The Malaysian Anti-Corruption Commission's (MACC) report. This data is important to show the level of corruption that occurs in Malaysia regardless of the economic status, position in the community and position held. Data in 2015 indicates a total of 841 arrests have been made from various work positions. Table 1 shows that from the total, 398 individuals or $(47.32 \%)$ are civil servants with nine individuals are from the highest management, 82 from the management and professional category and 307 from the executing group. The society contributes $52.68 \%$ which is equivalent to 443 arrests with a fraction number of 127 (private), 316 individual categories and zero cases for other categories.

Table 1: Arrests based on position (2015)

\begin{tabular}{|l|l|c|c|}
\hline NO & CATEGORY & $\mathbf{2 0 1 5}$ & PERCENTAGE \\
\hline 1 & CIVIL SERVANT & 398 & 47.32 \\
\hline & Highest management & 9 & \\
& Management and Professional & 82 & \\
& Executing Group & 307 & 52.68 \\
\hline 2 & PUBLIC & 443 & \\
\hline \multirow{2}{*}{} & Private & 127 & \\
& Individual & 316 & $\mathbf{1 0 0}$ \\
& Others & 0 & \\
\hline \multicolumn{2}{|l|}{ TOTAL } & $\mathbf{8 4 1}$ & \\
\hline
\end{tabular}

(Source: SPRM's report 2015, pg. 48)

Table 2: Arrests according to types of crimes (2015)

\begin{tabular}{|l|l|c|c|}
\hline \multirow{2}{*}{ NO } & \multirow{2}{*}{ CRIME } & \multicolumn{2}{|c|}{$\mathbf{2 0 1 5}$} \\
\cline { 3 - 4 } & & TOTAL & PERCENTAGE \\
\hline 1 & Receiving bribe & 449 & 53.39 \\
\hline 2 & Giving bribe & 93 & 22.95 \\
\hline 3 & False claim & 108 & 12.84 \\
\hline 4 & Abuse of authority & 24 & 2.85 \\
\hline 5 & Other crimes & 67 & 7.97 \\
\hline \multicolumn{2}{|r|}{ TOTAL } & $\mathbf{8 4 1}$ & $\mathbf{1 0 0}$ \\
\hline
\end{tabular}

(Source: SPRM's report 2015, pg. 49)

Based on statistics, arrests that involved the crime of corruption contributed to $53.39 \%$ of 449 arrests from the whole arrests in 2015. This was followed by arrests involving crime giving bribes of 93 arrests (22.95\%), arrests for crime to submit false claims of 108 (12.48\%), arrests for abuse of positions of $24(2.85 \%)$ and arrests for other crimes of 67 arrests $(7.97 \%)$. The 
detailed fraction of arrests that been made in the year 2016 were as stated in Table 3 . The total of arrests towards the public is $472(50.27 \%)$ with the private sector indicates 210 cases, individuals 239 cases while others involved 23 cases. In the civil servant's categories, there were a total of 467 cases (49.73\%) has been recorded with the arrest of highest management of seven cases, management and professional of 119 cases and 341 cases were from the executing group categories.

Table 3: Arrests based on position (2016)

\begin{tabular}{|l|l|c|c|}
\hline NO & CATEGORY & $\mathbf{2 0 1 6}$ & PERCENTAGE \\
\hline 1 & CIVIL SERVANT & 467 & 49.73 \\
\hline & Highest management & 7 & \\
& Management and Professional & 119 & \\
& Executing Group & 341 & 50.27 \\
\hline 2 & PUBLIC & 472 & \\
\hline \multirow{2}{*}{ TOTAL } & Private & 210 & \\
& Individual & 239 & 100 \\
& Others & 23 & \\
\hline
\end{tabular}

(Source: SPRM's report 2016, pg. 35)

Table 4: Arrests according to types of crimes (2016)

\begin{tabular}{|l|l|c|c|}
\hline \multirow{2}{*}{ NO } & \multirow{2}{*}{ CRIME } & \multicolumn{2}{|c|}{$\mathbf{2 0 1 6}$} \\
\cline { 3 - 4 } & & TOTAL & PERCENTAGE \\
\hline 1 & Receiving bribe & 462 & 49.20 \\
\hline 2 & Giving bribe & 192 & 20.45 \\
\hline 3 & False claim & 205 & 21.83 \\
\hline 4 & Abuse of authority & 28 & 2.98 \\
\hline 5 & Money laundering & 25 & 2.66 \\
\hline 6 & Other crimes & 27 & 2.88 \\
\hline & TOTAL & $\mathbf{9 3 9}$ & $\mathbf{1 0 0}$ \\
\hline
\end{tabular}

(Source: SPRM's report 2016, pg. 35)

According to the statistics, arrests that involved the crime of receiving bribes contributed to $49.20 \%$, which a number of 462 arrests from the total arrest in 2016 . This was followed by arrests that included giving bribes of 192 arrests (20.45\%), arrests for the false claim is 205 (21.83), for abuse of positions, 28 arrests (2.98\%), money laundering for 25 arrests equivalent to $2.66 \%$ and arrests for other crimes recorded for 27 arrests (2.88\%). A total of 879 arrests were made in 2017 and Table 5 shows a total of arrests according to the group in that year that indicates a decrease of $3 \%$ of the total number of arrests in the previous year. Civil servants who had been arrested were 409 (46.53\%), 168 people from the private sector were arrested representing $35.75 \%$ of the total public arrests that recorded 470 cases. The public still dominated the total of arrests of 470 people $(53.47 \%)$, while the arrests on high management increased to 13 peoples compared to the previous year. 
Table 5: Arrests based on position (2017)

\begin{tabular}{|l|l|c|c|}
\hline NO & CATEGORY & $\mathbf{2 0 1 7}$ & PERCENTAGE \\
\hline 1 & PENJAWAT AWAM & 409 & 46.53 \\
\hline \multirow{2}{*}{ Highest management } & 13 & \\
& Management and Professional & 101 & \\
& Executing Group & 295 & 53.47 \\
\hline 2 & PUBLIC & 470 & \\
\hline \multirow{2}{*}{ TOTAL } & Private & 168 & \\
& Individual & 30 & $\mathbf{1 0 0}$ \\
& Others & $\mathbf{8 7 9}$ & \\
\hline
\end{tabular}

(Source: SPRM's report 2017, pg. 46)

Table 6: Arrests according to types of crimes (2017)

\begin{tabular}{|l|l|c|c|}
\hline \multirow{2}{*}{ NO } & \multirow{2}{*}{ CRIME } & \multicolumn{2}{|c|}{$\mathbf{2 0 1 7}$} \\
\cline { 3 - 4 } & & TOTAL & PERCENTAGE \\
\hline 1 & Receiving bribe & 408 & 46.42 \\
\hline 2 & Giving bribe & 240 & 27.30 \\
\hline 3 & False claim & 142 & 16.15 \\
\hline 4 & Abuse of authority & 53 & 6.03 \\
\hline 5 & Money laundering & 17 & 1.93 \\
\hline 6 & Other crimes & 19 & 2.16 \\
\hline \multicolumn{2}{|r|}{ TOTAL } & $\mathbf{8 7 9}$ & $\mathbf{1 0 0}$ \\
\hline
\end{tabular}

(Source: SPRM's report 2017, pg. 47)

Based on statistics, arrests that include a crime of giving bribes contributed to $46.42 \%$ which was 408 arrests from the overall arrest in 2017. This was followed by arrests involving corruption of 240 arrests $(27.30 \%)$, the arrest for a crime to submit false claims of 142 (16.15\%), arrests for false claim, 142 cases (16.15\%), arrests for abuse of power is 53 cases (6.03\%), arrests for money laundering, 17 arrests (1.93\%) and other crimes recorded 19 cases (2.16\%).

Table 7: Arrests based on position (2018)

\begin{tabular}{|l|l|c|c|}
\hline NO & CATEGORY & $\mathbf{2 0 1 8}$ & PERCENTAGE \\
\hline 1 & CIVIL SERVANTS & 418 & 46.76 \\
\hline \multirow{2}{*}{ Highest management } & 13 & \\
& Management and Professional & 132 & \\
& Executing Group & 273 & 53.24 \\
\hline 2 & PUBLIC & 476 & \\
\hline \multirow{2}{*}{ TOTAL } & Private & 186 & \\
& Individual & 50 & $\mathbf{1 0 0}$ \\
& Others & $\mathbf{8 9 4}$ & \\
\hline
\end{tabular}

(Source: SPRM's report 2018, pg. 57) 
Table 8: Arrests according to types of crime (2018)

\begin{tabular}{|l|l|c|c|}
\hline \multirow{2}{*}{ BIL } & \multirow{2}{*}{ CRIME } & \multicolumn{2}{|c|}{$\mathbf{2 0 1 8}$} \\
\cline { 3 - 4 } & & TOTAL & PERCENTAGE \\
\hline 1 & Receiving bribe & 394 & 44.07 \\
\hline 2 & Giving bribe & 125 & 13.98 \\
\hline 3 & False claim & 231 & 25.84 \\
\hline 4 & Abuse of authority & 93 & 10.40 \\
\hline 5 & Money laundering & 21 & 2.35 \\
\hline 6 & Other crimes & 30 & 3.36 \\
\hline \multicolumn{2}{|r|}{ TOTAL } & $\mathbf{8 9 4}$ & $\mathbf{1 0 0}$ \\
\hline
\end{tabular}

(Source: SPRM's report 2018, pg.58)

In the year 2019, a total of 1,101 individuals were arrested and were the highest arrests made by the MICC throughout the five years. There was an increase in civil servant arrests of 107 individuals compared to the previous year. The increase in arrests was also recorded in the private sector, which was 225 compared to the past year, with only 186 people arrested. This year there was also a rise in arrests for the highest management category of 4 people who made 17 people compared to 13 people in 2018.

Table 9: Arrests based on position (2019)

\begin{tabular}{|l|l|c|c|}
\hline NO & CATEGORY & $\mathbf{2 0 1 9}$ & PERCENTAGE \\
\hline 1 & CIVIL SERVANTS & 525 & 47.68 \\
\hline \multirow{2}{*}{ High management } & 17 & \\
& Management and Professional & 121 & \\
& Executing Group & 387 & 52.32 \\
\hline 2 & PUBLIC & 576 & \\
\hline \multirow{2}{*}{ TOTAL } & Private & 255 & \\
& Individual & 27 & $\mathbf{1 0 0}$ \\
& Others & $\mathbf{1 , 1 0 1}$ & \\
\hline
\end{tabular}

(Source: SPRM's report 2019, pg. 34)

Table 10: Arrests according to types of crimes (2019)

\begin{tabular}{|l|l|c|c|}
\hline \multirow{2}{*}{ NO } & \multirow{2}{*}{ CRIME } & \multicolumn{2}{|c|}{$\mathbf{2 0 1 9}$} \\
\cline { 3 - 4 } & & TOTAL & PERCENTAGE \\
\hline 1 & Receiving bribe & 448 & 40.69 \\
\hline 2 & Giving bribe & 222 & 20.16 \\
\hline 3 & False claim & 315 & 28.61 \\
\hline 4 & Abuse of authority & 70 & 6.36 \\
\hline 5 & Money laundering & 17 & 1.54 \\
\hline 6 & Other crimes & 29 & 2.63 \\
\hline \multicolumn{2}{|r|}{ TOTAL } & $\mathbf{1 , 1 0 1}$ & $\mathbf{1 0 0}$ \\
\hline
\end{tabular}

(Source: SPRM's report 2019, pg. 34)

Based on the findings, it shows that the effort to combat corruption and abuse of power is an effort that needs to perform continuously, requires a strong and high commitment from all 
parties. The issue of why this corruption and abuse of power should be overcome earnestly because these symptoms have elements of oppression and tyranny such as the senior to the junior. The oppression and tyranny occur where injustice in the distribution of a gift to those in need. Corruption was rampant and abuse of power cause a continuous law of the jungle to occur in modern society through money and power used as a tool to control others

\section{Islamization in Malaysia}

Globalisation and the developments of technology and communication today have created changes that lead the organisation to the level of challenges in maintaining and increasing the organisation (Idros, et al., 2017). Islamization is act of bringing someone under the influence of Islam by infusing good values found in the teaching of Islam (Mohd Shukri, 2014). In Malaysia's context, Islamization is the process of applying Islamic value in all aspects implemented by the Government of Malaysia (Fadhli, 2001). The process of Islamization aims to produce quality role model and communities who are excellent in physical and spiritual aspects. As it is known, the teaching of Islam is progress and civilization. If Islam is understood and practiced, progress will be achieved (Rahman, et al., 2009). The government has launched numerous campaigns and policies to overcome the misconduct problem, abuse of power, corruption among the civil servant. This is also one of the strategies to enhance the service level serve to the people in this country by upholding good values. The government main policy can be divided to two parts; Public Policy and Development Policy, while the meaning of policy literally means to achieve the aim (Government Main Policy, 2010).

Since the 1980's especially under the administration of former Prime Minister, Dato' Seri Mahathir Mohamad, by introducing numerous policies and campaigns as an effort to combat power abuse among the civil servants. Among the policy and campaign introduced are the policy of Clean, Efficient and Trustworthy, Leadership by Example, Inculcation of Islamic Value Policy, Vision 2020, Excellent Work culture, Work Ethics Code, Clients Charter, and ISO 9000 (Government of Malaysia, National Integrity Plan, 2004). The rational for the application of good values in the administration is to establish Malaysian identity that are respected by other communities based on applied and practiced values, positive and acceptable universally by all races and religions in Malaysia, who known as multicultural and multi-religious. Objectives of this policy are:

1. To ensure Malaysians are reliable, with good images abroad and respected by others

2. Created a happy condition

3. To remove negative attitude in performing duties assigned

4. To produce quality service

Values suggested to be practiced by the Malaysian are responsible, sincere, discipline, cooperative, and (Government main policy). This research will only discuss briefly four from numerous campaign and policy namely:

i. Clean, Efficient, Trustworthy Policy

ii. Leadership by Example

iii. Inculcation of Islamic Value Policy

iv. Vision 2020

v. National Integrity Plan (NIP 2003-2008) 


\section{i. Clean, Efficient, Trustworthy Policy}

The wise behind the introduction of this campaign is to remind the people that the development and success of a country depend on positive attitude and high moral behaviour from managers, and communities. On this fact, awareness should be raised in the office, civil and private servants, and the people overall, so that they understand their duties and responsibilities and performing them effectively and efficiently. Besides that, they need to obey good moral policies and have reliable attitudes, to ensure they are able to deliver the best quality of service to the public.

The perception of civil servants that they work entirely for their own personal needs because of salary and wage should get rid of, but the spirit of working for the people's benefit should be executed into the souls and minds of everyone, especially among the civil servants. This policy is a framework that has been introduced and is expected to achieve this goal. The main objective of this policy is introduced as follows;

1) Establish new work ethics and service attitude in Malaysia, to give priority to increase the income (productivity) and work quality

2) To enhance the spirit or motivation of employees in line with the application of Islamic Value and Leadership by Example

Particularly, the intended attitude and character to be applied to all the employees and people are as Clean - to have high moral, good attitude and discipline, free of malpractice and corruption, Efficient - brave and able to make decisions quickly, Trustworthy - prepared to carry out duties and responsibilities within the boundaries and powers, with determination, diligent to achieve the determined objective and to own noble and pure attitude, honest to themselves, friends and organizations.

This policy is a good concept introduced by the government. These attitudes are the important basis in creating a civilized Malaysian community and having high moral values in line with Islam as the official religion of the country following with the Malaysian Constitution. Therefore, this concept cannot be separated and should move forward with the implementation of the conceptual concept of assessment, aspirations and ideas of leadership by example and principle of Rukun Negara. Generally, the slogan of the policy has a great impact on administrative performance and achieving high productivity through the application of ethical and progressive values for work in accordance with the good terms of moral practice consistent with the purpose of this policy.

\section{ii. Leadership by Example}

The concept of Leadership by Example has been launched on the $19^{\text {th }}$ May 1983. The purpose of this campaign is to produce, foster and nourish leadership culture among the civil servants, so they will appreciate leadership values and noble behaviour driven by excellent examples from clean, efficient, trustworthy leadership. In addition, the purpose of this campaign is to increase the practice and productivity of clean, efficient and trustworthy that have been launched before. This campaign basically is a continuation of the introduction of the first policy. Campaign of Leadership by Example is the fundamental that aims to change the attitude, achieve and strengthening work ethical value and enhancing the government's power. It is consistent, balanced and communicative with the basic principles such as Look 
East Policy, Clean, Efficient and Trustworthy, and Inculcation of Islamic Value in the administration forming the campaign basis. Therefore, it is focusing on the implementation previous campaign, with improved information and values.

Objective of this campaign is to put and foster effective values of leadership that can provide examples, practiced by the people, moral values and ethics and the sense of responsibility among the people, especially civil servants and to change the attitude to achieve and strengthening values and work ethics and increasing the productivity of the country. Positive characteristics that should be performed and followed by the community in general as an example as follows; Simplicity in action and speech, have a clear vision and strategy and a high moral set, own a clean heart, mind and action, constantly improving and developing their abilities, and possess high integrity and be prudent in performing their duties. Mostly, the purpose of this campaign is to remind all positions in the high ranking either in the public sectors and politicians or statutory bodies, to show and behave with good manners, so the public and society will set the leader as an example. By showing good moral attitudes, officers in government sectors and statutory bodies will be a good example to the public to practice pure values in their daily lives.

\section{iii. Inculcation of Islamic Value Policy}

In line with the Islamization program, Islamic values are universal values that align the development of material and spiritual aspects. The implementation of Islamic policy values in administration is part of numerous efforts to introduce and implement Islamic foundation elements in the living of Malaysians. The rationale for the attention given by the government with values, especially Islamic Values is (Inculcation of Islamic Value Policy in administration, 2008);

"In order to preserve the dignity of Malaysians, so we need to have a strong identity. In this context, a crucial element in the formation of the identity of Malaysian is value. It is a major factor to ensure the existence of a respected society. A nation that does not own a certain value of life will become a victim easily to other nations who are always trying to develop their values and with this progress will be able to control the nation who does not own a strong value"

Malaysian society consists of various races and different religions in terms of life and values then emphasis should be given to the values that acceptable to all in effort to create an identity and move towards community unity. Without this universal value, the community will be tempted to accept and practice other values and odd to the Malaysian community. This will cause the loyalty and identity of the people to become uncertain and have low moral self-esteem towards their own country. Malaysians need to own their identity, so that all activities performed by individuals, organizations in the sector can make a greater contribution to national prosperity (Inculcation of Islamic Value Policy in administration, 2008). Islamic Values can be a stimulus to eliminate elements that give a bad name to the country, which can be considered as the main enemy of the country. Elements such as communist ideology, poverty, corruption, negligence, and ignorance are elements that threaten all the efforts for the unity of the people, the country and to promote development. The Quran also prescribes Islam as a value religion. The recognition is thus given everyone confidence that the Quran contains values and guidance from Allah and directed to all the people, not only to the Muslims (Inculcation of Islamic Value Policy in administration, 2008). 
This guideline is about the most important matter that is moral. This means the meaning of the application of basis values in Islamic Management Guidelines is a comprehensive and functioning formation in everyone's life, towards increasing the self-esteem at a high level in moral purity and behaviour among the people and state officials from the Federation of Malaysian. Only 11 from Islamic Values have been chosen to form this statement of principle policy. Eleven values that can be accepted as the key to success in performing life affairs and mainly in managing this country; Trust, Responsibility, Sincerity, Dedication, Moderate, Diligent, Clean, Discipline, Cooperate, Grateful (Inculcation of Islamic Value Policy in administration, 2008). These 11 values are selected because it is an acceptable element as the key to success in carrying out life affairs especially in the administration of the country.

The choice of the country's administration as the first component of the infusion of Islamic values is based on the government's responsibility to ensure the smoothness of government administrative which is the most important channel in the implementation of a policy. The success of plans organized by the government determined by the civil servants. The acknowledgement of Islamic values by them will ensure the smoothness and efficiency of large government workers and avoid corruption, malpractice and others (Inculcation of Islamic Value Policy in administration, 2008). The value that given priority for the administration to be applied to all Muslims and non-muslins are beliefs, honesty, responsibility, diligence, sincerity, discipline, be considerate to other communities as well, willing to sacrifice, not greedy, good moral and behaviour and others (Inculcation of Islamic Value Policy in Administration, 2008)

\section{iv. Vision 2020}

During the launch of the Trade Council on 28 February 1991, Former Prime Minister Mahathir Mohamad has presented a paper entitled 'Malaysia-Moving Forward' containing a framework thinking about goals with Malaysia's goals to become a developed country by 2020, knowns as 'Vision 2020'. It is not a policy but a specific respond for the development of the economy, social and political changes at the national and international level that were challenges to this country. This vision has been highlighted as a guideline and framework on approaches that must be taken for the country to achieve developed country status. This vision is the most important fundamental to any programmes and planning created by the government today.

The ultimate objective that we aim for is for Malaysia to be a fully developed country by the year 2020. It is not limited only to the economy, but includes all aspects of life; economic, political, social, spiritual, and cultural. By the year 2020, Malaysia as an independent country will be fully developed, united, able to act free and prosperous. People will enjoy life the perfect life in society, tolerance, morals, justice, the democracy of economic competition and dynamic culture. This indicates Vision 2020 aims to establish Malaysia as a developed country in its own way. The desired progress is progress not only measured physical achievement solely but will create a perfect community with social values and ethical standards that can be an example to other countries. This aim can only be achieved if Malaysians can face and overcome various obstacles that considered as a challenge (Prime Minister's Office, Vision 2020's perspective, 2008). 


\section{v. National Integrity Plan (NIP 2003-2008)}

National Integrity Plan has been enacted by predicted upon the spirit and principles of the Federal Constitution. The reality of the life of Malaysian society that comprising various religions and races is a gift and advantage to be utilized. NIP also encompassing the philosophy and principles of Rukun Negara, to build united, fair, democratic, liberal and progressive and adhere to the 5 principles of Rukun Negara. The NIP also guided by the aspiration and challenge of Vision 2020 towards creating a developed country by own mould by 2020.

The NIP approach is to coordinate the efforts of all components and sectors in the integrity stabilization movement. NIP requires the entire country's governance institution namely executive, legislature, and judiciary to enhance their integrity, respect and defend the principle of separation of power, and carry out their own functions efficiently, transparent, fair and effective (Prime Minister's Office, 2010). The general objective of the NIP is to realize the aspirations of vision 2020, which is to become a fully developed country in our own mould by forming society with strong moral and ethical values, whose citizens are strong in religious and spiritual values, and imbued with the highest ethical standards with five specific objectives as follows; giving direction and guidance to numerous sectors so that they will work together in to build a united, harmony, integrity, moral, ethical society; Increasing the level of awareness, commitment, cooperation among all sectors in their efforts at enhancing so that integrity becomes a way of life and practiced in all fields, encouraging responsibility spirit among members of the community and promoting the development of civil society that respects and uphold the principles of integrity, Contributing to the effort of strengthening the moral foundations of the community and the country, improving the well-being of the people, raising Malaysia's competitiveness and resilience in meeting the challenges of twenty-first century, especially the challenges of globalisation effectively (Institute of Integrity Malaysia, 2004).

To ensure the dignity of Malaysian society is always preserved, they need to have a strong identity and the most important element in the formation of social identity is value. It is crucial to make Malaysia as a country that has a respected society. A nation who do not have their own value of life is weak and easily influenced. They will also become a victim to a strong nation who always looking for changes to influence and introduce their value into the mind of a weak nation, as well as taking control of the mind and value of the community.

\section{Discussion}

Even though various campaigns and policies have been implemented by the government, but the effectiveness still cannot be categorized as successful. The amount and percentage of those who arrested because of misconduct and corruption did not show significant improvement. Amount of arrests constantly increasing from year to year. This situation shows that there are still many civil servants working without high value and integrity. The study shows that a work culture of integrity refers to competitive work culture, having a clear mission and direction and has good morals and attitude (Akrimi \& Anuar, 2017). More surprisingly, the problem of corruption occurs massively among the highest management category. This shows that not only the financial problems that causes corruption to occur but the level of knowledge and religious practice that is less emphasized and less trust in the law enforcement agency have contributed to the widespread of this problem (Obasola, 2013; Costello \& Vowell, 1999). Sufiean et. al., (2018) found that the practice of religion and 
volunteerism among the youth are expected to enhance moral and integrity values. The findings also show that the religious aspect has a significant relationship with social integration among the people under surveillance (Fauziah, et al., 2020).

Corruption and abuse of power are like cancer and it has existed in society for a long time. So, it is the responsibility of all units in the community together to fight against and staying corruption-free before it turns out to be a silent killer in the community and their work culture. The effect of corruption practices and abuse of power on the integrity of society and the country is the existence of a cruel, inconsiderate, and selfish society and the absence of a positive attitude that should be in an individual. The effect of it will produce a weak, uncompetitive, an undignified society that will lead the country to be backward, weak and all planning towards the development of the country cannot be implemented successfully as the outside community will lose confidence in the integrity of the community and government of Malaysia.

\section{Conclusion}

As a multicultural country where the people carry out different way of life between one another, the practice of these universal value (in the context of Malaysia) and acceptable to all levels of society is the necessary base to form identity and unity. Without this universal values, then the people will tend to accept and uphold the culture and values. Values that are acceptable by the Muslim and non-Muslims are trust, honesty, responsible, diligent, sincerity, well mannered, discipline, prioritize the society more than themselves, willingness to sacrifice, not greedy, ethical, and well behaved. Honesty and sincerity are something that can be felt and expressed but integrity is beyond that where both of the values need to be seen and evaluated by the community or other countries. Many countries practicing corruption are living backward and life of their people are poor and depressing. Such situations will easily attract various other social problems such as blackmail, kidnapping, murder to earn money for a living that affected due to the effect of corruption practice and abuse of power that widespread in the society.

Corruption and abuse of power are like cancer and it has existed in society for a long time. So, it is the responsibility of all units in the community together combat and staying corruptionfree before it turns out to be a silent killer in the community and their work culture. The effect of corruption practices and abuse of power on the integrity of society, nation and the country is the existence of cruel, inconsiderate, and selfish society and absence of positive attitude that should be in an individual. The effect of it will produce a weak, uncompetitive, undignified society that give an impact on the development of a backward and weak country. The planned development of all aspects of life will also be affected, easily oppressed, and lack of strength to confronting the current wave of globalization effect from distrust of world community towards a country that involved in corruption and abuse of power. Undoubtedly, the country will not able to move forward to compete with others world powers. The effort of the government to introduce policies and campaigns towards the infusion of Islamization in the behaviour of the people should be praised. However, without cooperation from all parties, hope remains as hope, and there is a possibility that will not able to be realized. 


\section{References}

Abdull Rahman, M., Kamaruddinm, S., Ahmad, S. L., \& Faudzinaim, B. (2009). Penerimaan bukan Islam Terhadap Proses Islamisasi di Malaysia. Jurnal Hadhari, 2, 33-51.

Ahmad, F. S. (2001). Islamisasi di Malaysia: Satu Sorotan Pencapaian. [Online]. Available at: https://dokumen.tips/documents/islamisasi-di-malaysia.html. [Accessed 14 Februari 2020].

Blackburn, K. (2019). Corruption and Development: Explaining the Evidence', Centre for Growth and Business Cycles Research, Department of Economics, University of Manchester, pp.1-37. [Online]. Available at: http://www.dur.ac.uk/resources /dbs/faculty/BlackburnGl-Conf2009.pdf [Accessed on 25 th January 2019].

Costello, B. J., \& Vowell, P. R. (1999). Testing control theory and differential association: A reanalysis of the Richmond Youth Project data. Journal Criminology. 37(4), 815-842.

Fauziah, I., Shahrazad, W. S., Ezarina, Z., \& Rahim, M. K. (2020). Pengintegrasian Sosial: Sejauhmana hubungannya dengan kesihatan diri, keagamaan dan jaminan pekerjaan dalam kalangan orang kena pengawasan. Malaysian Journal of Society and Space, 16 (3), 35-146.

Kerajaan Malaysia, Pelan Integriti Nasional. (2004). Membina Masyarakat Maju Menurut Acuan Sendiri. Kuala Lumpur: Jabatan Perdana Menteri.

Fauzi, M. H. H. (2001). Jenayah Rasuah di Agensi Penguatkuasaan Undang-undang di Malaysia: Satu Analisis Persepsi Pegawai Awam di Unit Pencegahan Penyeludupan di negeri Kelantan. Tesis Sarjana. Kedah: Universiti Utara Malaysia.

Sufiean, M. H., Maizatul, H. M., \& Helmi, M. A. R. (2018). Skala Psikometrik: Perspektif Kawalan Sosial Tidak Formal dan Pengukuhan Nilai Integriti Golongan Muda. Jurnal Komunikasi Malaysian Journal of Communication, 34(4), 232-249.

Shukri, M. H. (2014). The Wasatiyyah (Moderation) Concept in Islamic Epistemology: A Case Study of its Implementation in Malaysia. International Journal of Humanities and Social Science, 9(1), 51-62

Nor Akrimi, M. A., \& Anuar, P. (2017). Penghayatan Ihsan Sebagai Medium Pengukuhan Budaya Kerja Berintegriti. Fikiran Masyarakat, 5 (3), 6-12.

Nur Hafizah, Y. (2019). Integriti akademik dalam kalangan mahasiswa Universiti Kebangsaan Malaysia (UKM). Malaysian Journal of Society and Space, 15(4), 179-190.

Obasola, K. E. (2013). Religious imperatives as a panacea to crime and violence among youths in Nigeria. European Journal of Business and Social Sciences, 2(8), 12-122.

Prime Minister's Office. (2009). 'Dasar Penerapan Nilai-nilai Islam dalam Pentadbiran, $14^{\text {th }}$ November 2008. Available at: http://pmr.penerangan.gov.my/index.php? option=com_content \& view=article\&id=243\%3Adasar-penerapan-nilai-nilai-islamdalam-pentadbiran\&catid=88\%3Adasar-dasar-negara\&Itemid=20. $\quad$ (Accessedon 15/7/2009).

Prime Minister's Office. (2010). Tun Abdullah Ahmad Badawi was the fifth Prime Minister who served Malaysia from 2003-2009, 18 Jun 2010. Available at: http://www.pmo.gov.my/?menu=page\&page=1880. (Accessed on 20/5/2011).

Prime Minister's Office. (2020). Perspektif Wawasan 2020, $14^{\text {th }}$ November 2008. Available at: http://pmr.penerangan.gov.my/index.php?option=com_content\&view=article\&id =255: perspektif-wawasan-2020\&catid=88: dasar-dasar-negara.

Peters, A. (2019). Corruption as a Violation of International Human Rights. European Journal of International Law, 29 (4), 1251 -1287, https://doi.org/10.1093/ejil/chy070

Suruhanjaya Pencegah Rasuah (SPRM). (2016). Laporan Tahunan 2015. Putrajaya: Malaysia. 
Suruhanjaya Pencegah Rasuah (SPRM). (2017). Laporan Tahunan 2016. Putrajaya: Malaysia. Suruhanjaya Pencegah Rasuah (SPRM). (2018). Laporan Tahunan 2016. Putrajaya: Malaysia. Suruhanjaya Pencegah Rasuah (SPRM). (2019). Laporan Tahunan 2016. Putrajaya: Malaysia. Suruhanjaya Pencegah Rasuah (SPRM). (2020). Laporan Tahunan 2016. Putrajaya: Malaysia. Idros, W. S., Farhah, N. O., \& Maizatul, H. M. (2017). Hubungan Pengkomunikasian Budaya Organisasi dengan Prestasi Kerja Kakitangan Pelaksana Sektor Awam. Journal of Social Sciences and Humanities, 12(3), 1-18. 